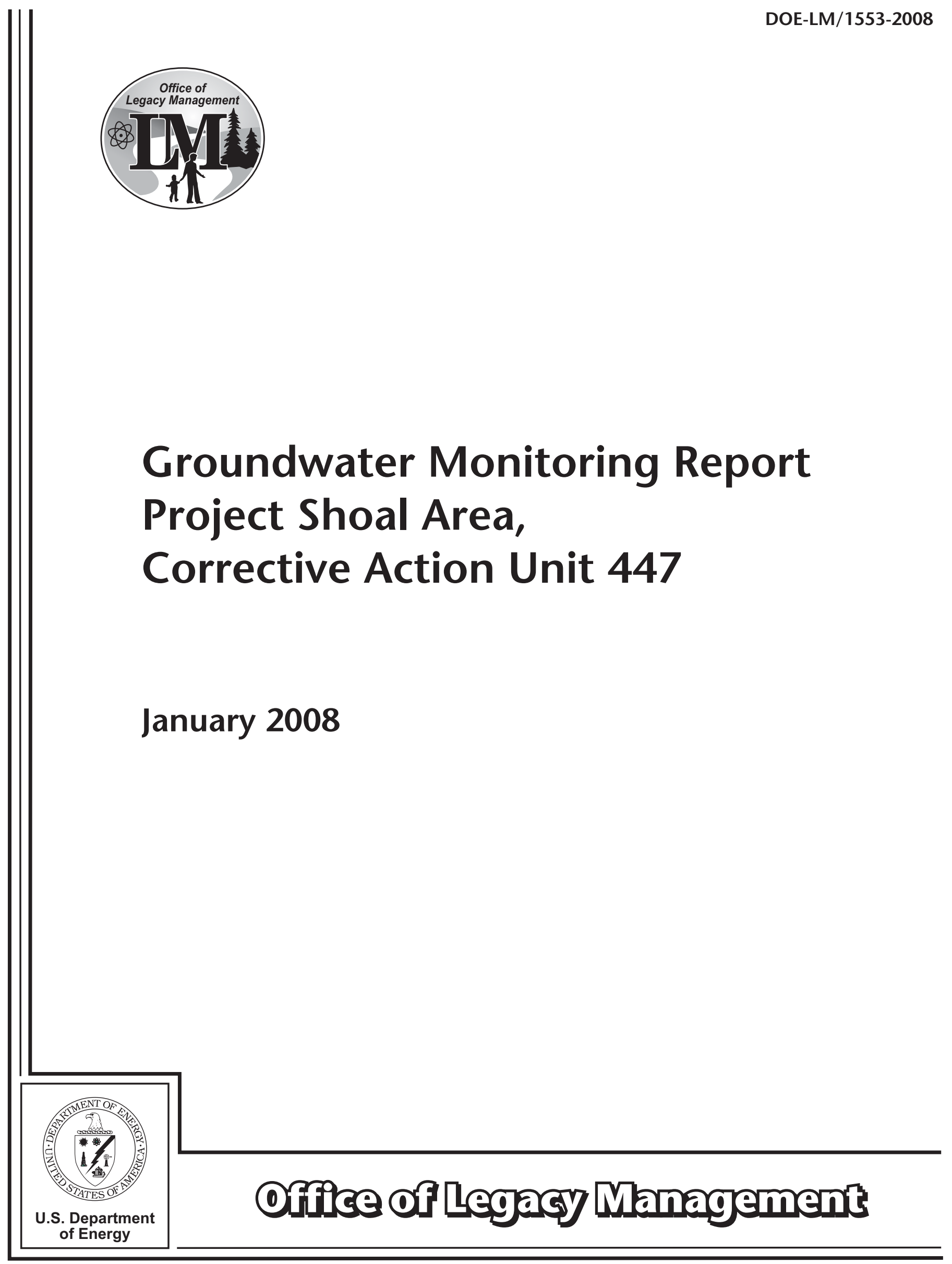


This page intentionally left blank 
DOE-LM/1553-2008

\section{Groundwater Monitoring Report Project Shoal Area, Corrective Action Unit 447}

January 2008

Work Performed by S.M. Stoller Corporation under DOE Contract No. DE-AC01-02GJ79491 for the U.S. Department of Energy Office of Legacy Management, Grand Junction, Colorado 
This page intentionally left blank 


\section{Contents}

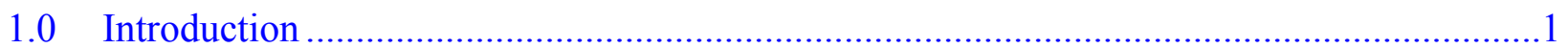

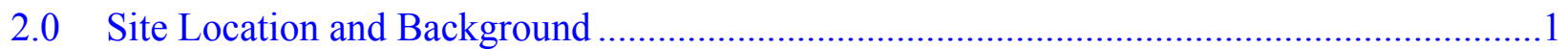

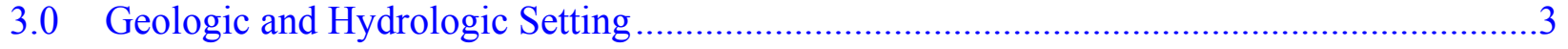

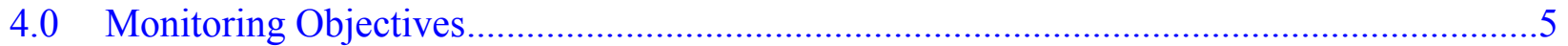

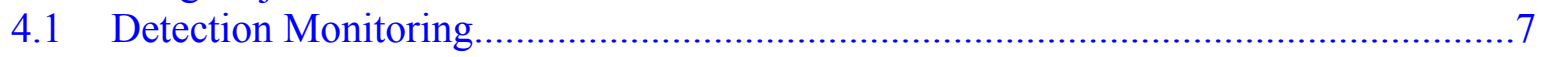

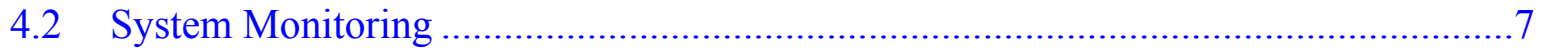

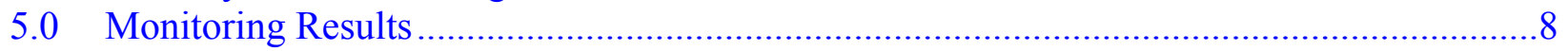

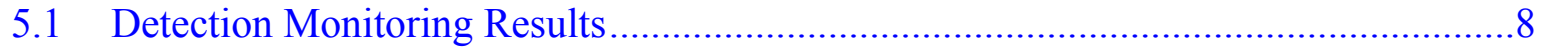

5.2 System Monitoring Results...................................................................... 10

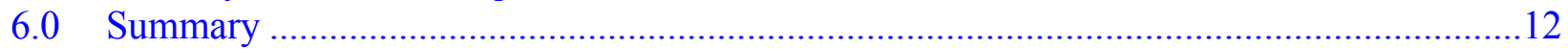

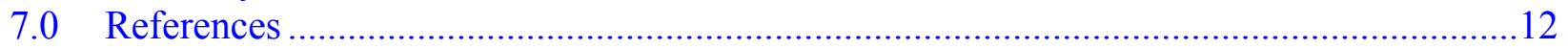

\section{Figures}

Figure 1. Location Map of Project Shoal Area ................................................................ 2

Figure 2. Wells and Other Features at the Project Shoal Area. .............................................. 4

Figure 3. Approximate Location of the Shear Zone ........................................................ 6

Figure 4. Time-Concentration Plot of Tritium at Well HC-4 ................................................ 10

Figure 5. Hydrographs for Wells West of the Shear Zone ...................................................... 11

Figure 6. Hydrographs for Wells East of the Shear Zone...................................................... 11

\section{Tables}

Table 1. Construction and Head Data for Wells at the PSA ................................................... 5

Table 2. Radioisotopic and Chemical Sampling Results .................................................. 9

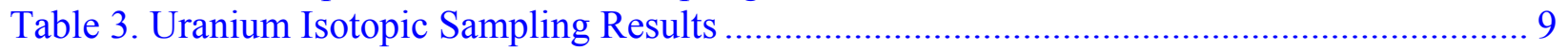

\section{Appendix}

Appendix A Carbon-14 Calculation Data and Well Purge Data 


\section{End of current text}

Page iv 


\subsection{Introduction}

This report presents the 2007 groundwater monitoring results collected by the U.S. Department of Energy (DOE) Office of Legacy Management (LM) at the Project Shoal Area (PSA)

Corrective Action Unit (CAU) 447 located in Churchill County, Nevada. Responsibility for the environmental site restoration of the PSA was transferred from the DOE Office of Environmental Management (DOE-EM) to DOE-LM on October 1, 2006. Requirements for CAU 447, as specified in the Federal Facility Agreement and Consent Order (FFACO 2005) entered into by DOE, the U.S. Department of Defense (DOD), and the State of Nevada, includes groundwater monitoring in support of site closure. This is the first groundwater monitoring report prepared by DOE-LM for the PSA.

\subsection{Site Location and Background}

The PSA is located south of U.S. Highway 50, approximately 30 miles southeast of Fallon, in Churchill County, Nevada (Figure 1). The Project Shoal underground nuclear test was performed on October 26, 1963, as part of the Vela-Uniform program sponsored jointly by DOD and the U.S. Atomic Energy Commission (AEC). The test consisted of detonating an estimated 12-kiloton nuclear device in granitic rock at a depth of approximately 1,211 feet (ft) below ground surface (bgs) (AEC 1964). A cavity created by the test collapsed shortly after the detonation and formed a rubble chimney (Pohll et al. 1998). The radius of the cavity is reported to be $85 \mathrm{ft}$ (26 meters) (Hazelton-Nuclear Science Corporation 1965).

Site deactivation and post shot drilling activities began on October 28, 1963. Re-entry drilling indicated that the Shoal test created a rubble chimney that was approximately $171 \mathrm{ft}$ in diameter and extended approximately $356 \mathrm{ft}$ above the shot point (Hazleton-Nuclear Science Corporation 1965). The decontamination and restoration activities were minimal because no large areas of contamination were found during or following the test. A radioactive materials survey was conducted at the site in 1970. The survey results indicated there were no radiological levels that exceeded background levels for the area. During this effort the PM, ECH, and BSM boreholes on the site were plugged and abandoned (AEC 1970). The shaft used to emplace the detonation device was backfilled and plugged in 1996.

Surface and subsurface CAUs were identified at PSA and addressed through separate investigation and evaluation processes. Remediation of surface CAU 416 was completed in 1998 and summarized in the Closure Report for CAU No. 416, Project Shoal Area (DOE/NV 1998). The Nevada Division of Environmental Protection (NDEP) approved the Closure Report on February 13, 1998, stating no post-closure monitoring is required and no land use restrictions apply at CAU 416 (NDEP 1998).

The corrective action process for subsurface CAU 447 has not been completed. This CAU is currently within the 5-year proof-of-concept monitoring phase. Monitoring comprises part of the corrective action alternative that was selected for this CAU, as presented in the Corrective Action Decision Document/Corrective Action Plan (CADD/CAP; DOE/NNSA 2006). Since 


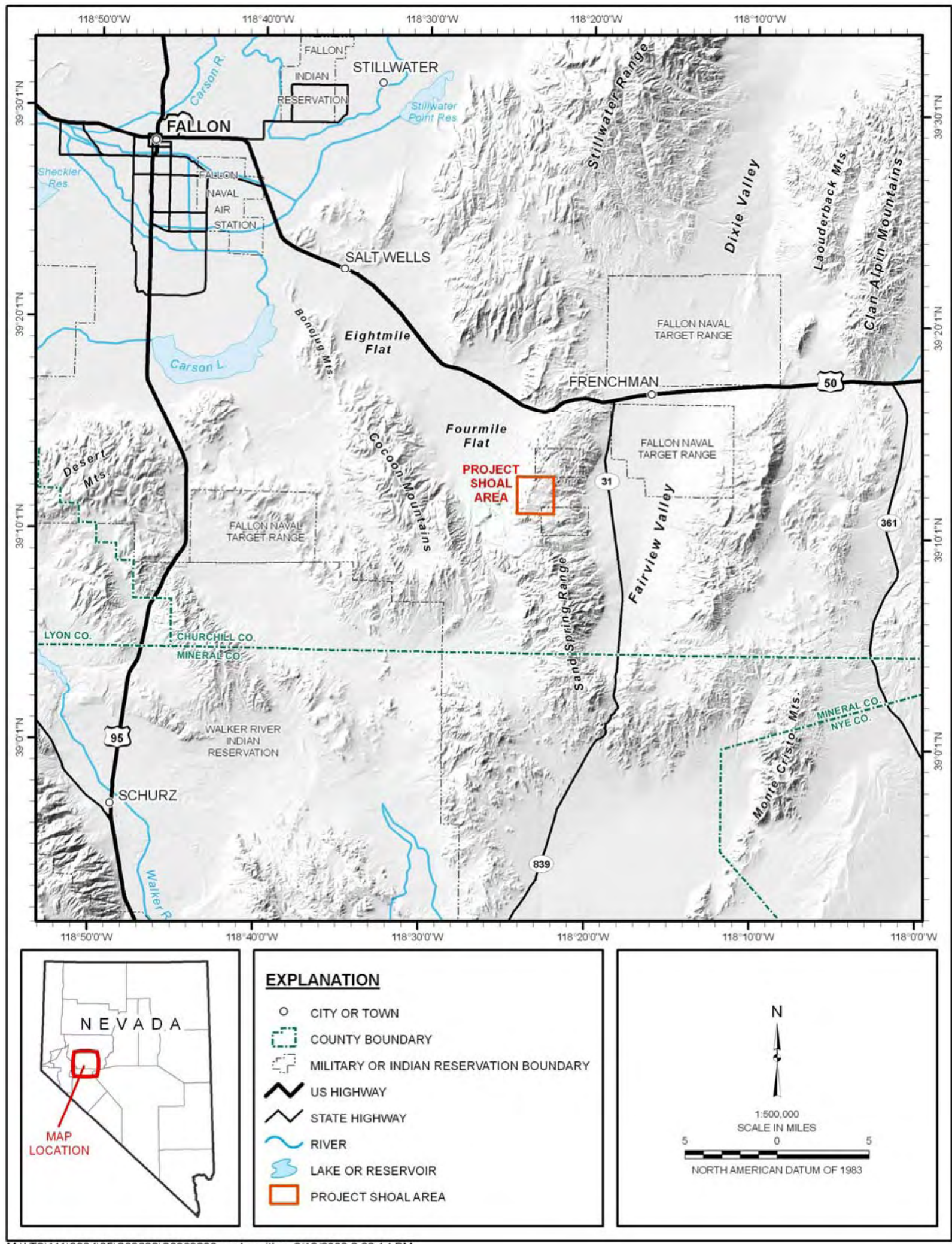

M:LTSI1111008405IS03682IS0368200.mxd smithw 2/13/2008 2:33:14 PM

Figure 1. Location Map of Project Shoal Area 
there is no known technology to remediate the remaining subsurface radioactivity, a groundwater flow and transport model was developed to determine a contaminant boundary, which establishes a restricted region surrounding the nuclear detonation. The contaminant boundary (Figure 2) is determined by numeric simulation of radionuclide movement in the groundwater over a period of 1,000 years. The boundary represents a distance beyond which groundwater is considered safe for use throughout 1,000 years (i.e., dissolved radionuclide concentrations are at or below maximum contaminant levels [MCLs]). The groundwater flow and transport model was developed by Desert Research Institute (DRI). The recommendation for the selected corrective action alternative within the CADD/CAP was based largely on the results of the numerical model of groundwater flow and radionuclide transport. The FFACO requires that numerical models be validated as part of the proof-of-concept monitoring.

As part of the monitoring plan and model validation process, three monitoring/validation (MV) wells were installed at the PSA during fiscal year (FY) 2006 (Figure 2). A well and a piezometer at a shallower depth were installed in each borehole. The wells were installed according to the $\mathrm{CADD} / \mathrm{CAP}$ with the purpose of establishing a monitoring network for proof-of-concept monitoring and for collecting data for the validation of the numerical model used to establish the contaminant boundary. Data collected from the wells during drilling and shortly after completion are currently being used to assess model validation (Hassan 2004). These data included samples for chemical and radiochemical analysis. The first sampling as part of the monitoring network occurred in FY 2007 and is reported here.

\subsection{Geologic and Hydrologic Setting}

The PSA is located in the northern portion of the Sand Springs Range in west-central Nevada's Churchill County. The Sand Springs Range is the southern extension of the Stillwater Range, a north-northeast-trending fault block range that traverses Churchill County. The Sand Springs Range rises to an elevation of approximately 6,751 ft above mean sea level (amsl) and is flanked by Fourmile Flat to the west and Fairview Valley to the east (Figure 1). The Shoal Site is located in Gote Flat at an elevation of approximately 5,250 ft amsl and is within an area that is part of the Cretaceous-age Sand Springs granitic batholith.

The Sand Springs batholith is composed of granodiorite and granite, aplite and pegmatite dikes, andesite dikes, rhyolite dikes, and rhyolitic intrusive breccia. Internal deformation of the Sand Springs granite is largely by high-angle normal faults that strike northeast and northwest, joints that parallel the northwest-trending faults, and fracture cleavages that generally parallel the northeast-trending faults. These faults, joints, and fractures are distributed between two dominant structural trends that generally strike $\mathrm{N} 50^{\circ} \mathrm{W}$ and $\mathrm{N} 30^{\circ} \mathrm{E}$ and are vertical-to-steeply dipping. Several dikes of varying composition predominantly follow the same two orientations and intrude along these lines of preexisting weakness. These orthogonal-type sets of faults and fractures appeared early in the history of the Sand Springs granite and affected much of the subsequent structural and chemical evolution of this large intrusion (Beal et al. 1964). 


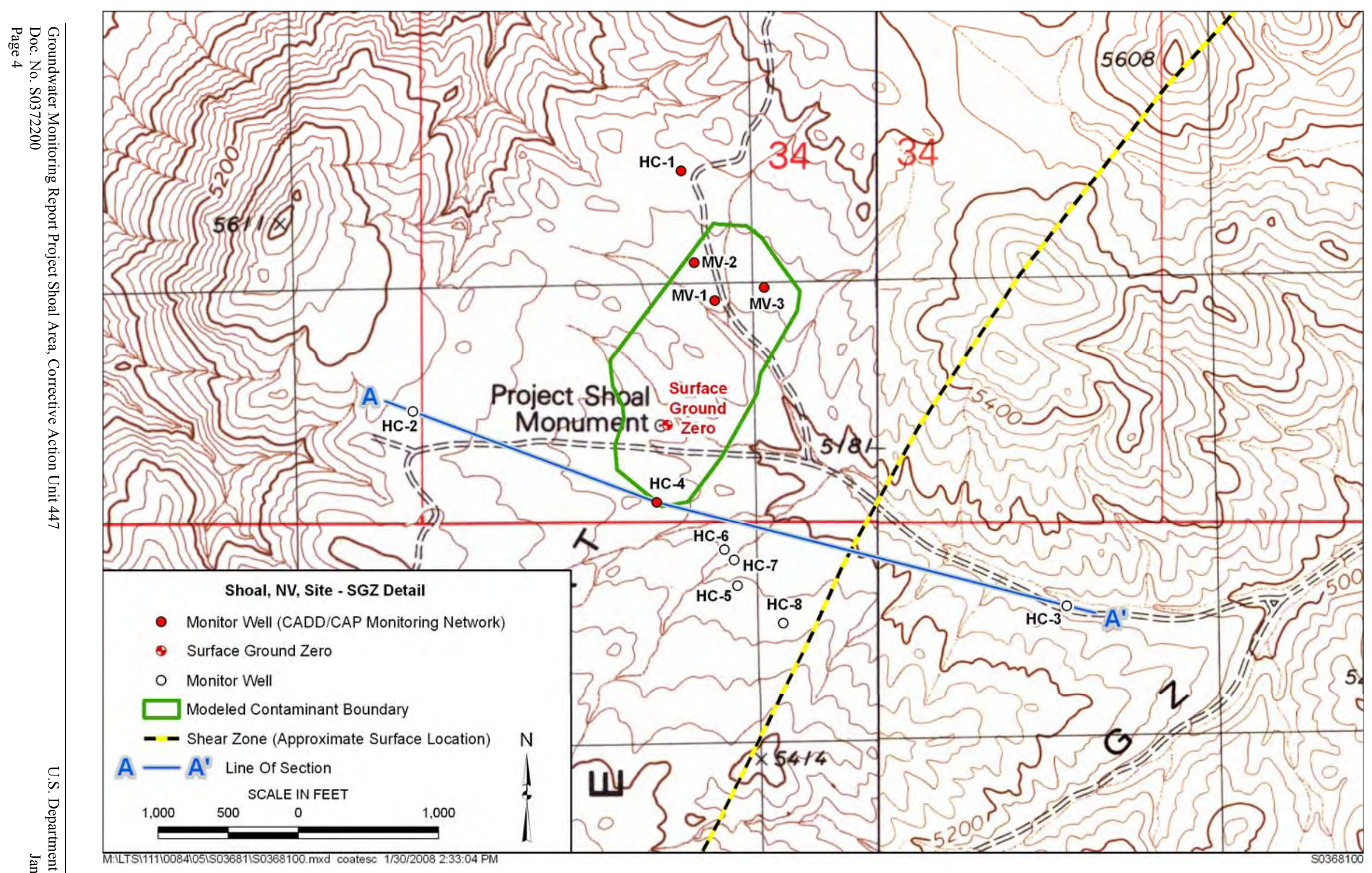

Figure 2. Wells and Other Features at the Project Shoal Area. 
The water table is present beneath the site at depths ranging from approximately 975 to $1,090 \mathrm{ft}$ bgs. Groundwater moves primarily through fractures in the granite. Groundwater recharge occurs by infiltration of precipitation on the mountain range, with regional discharge occurring in the valleys. A groundwater divide along the upland area of the range separates flow to the east and west, and a shear zone, located about 1,500 ft east of the site (Figures 2 and 3), is also a barrier to flow due to its low hydraulic conductivity. Groundwater within Fairview Valley has been used for ranching, seasonal residential purposes, and military uses within the last 5 years.

\subsection{Monitoring Objectives}

The monitoring network at the PSA consists of wells and piezometers in MV-1, MV-2, and MV-3, and the wells HC-1 and HC-4 (Figure 2). Monitoring at these locations includes the collection of hydraulic head data and groundwater samples for radioisotopic analyses as specified in the CADD/CAP (DOE/NNSA 2006). The general objectives of the monitoring are (1) "detection monitoring" to identify any releases of contamination from the test cavity itself and (2) "system monitoring" to ensure the overall stability (quasi-steady state) of the hydrogeologic system. Samples for radioisotopic analysis are collected annually during the proof-of-concept monitoring period. A summary of well construction information and hydraulic head data obtained in May 2007 for all wells at the site is presented in Table 1.

Table 1. Construction and Head Data for Wells at the PSA

\begin{tabular}{|c|c|c|c|c|c|c|c|}
\hline Well/Piezometer & $\begin{array}{c}\text { TOC } \\
\text { Elevation } \\
\text { (ft amsl) }\end{array}$ & $\begin{array}{c}\text { Water } \\
\text { Depth (ft) }\end{array}$ & Date & $\begin{array}{c}\text { Elevation } \\
\text { Water } \\
\text { (ft amsl) }\end{array}$ & $\begin{array}{c}\text { Elevation } \\
\text { TSZ } \\
\text { (ft amsl) }\end{array}$ & $\begin{array}{c}\text { Elevation } \\
\text { BSZ } \\
\text { (ft amsl) }\end{array}$ & $\begin{array}{l}\text { Screen } \\
\text { Length } \\
\text { (ft) }\end{array}$ \\
\hline MV-1 & $5,257.54$ & 997.31 & $5 / 22 / 2007$ & $4,260.23$ & $3,684.81$ & $3,531.00$ & 153.81 \\
\hline MV-1 PZ & $5,257.30$ & 986.59 & $5 / 22 / 2007$ & $4,270.71$ & $3,919.80$ & $3,859.80$ & 60.00 \\
\hline MV-2 & $5,266.62$ & $1,005.90$ & $5 / 22 / 2007$ & $4,260.72$ & $3,446.75$ & $3,275.98$ & 170.77 \\
\hline$M V-2 P Z^{c}$ & $5,266.51$ & $1,136.75$ & $5 / 22 / 2007$ & $4,129.76$ & $4,078.82$ & $4,019.32$ & 59.50 \\
\hline MV-3 & $5,261.50$ & 983.31 & $5 / 22 / 2007$ & $4,278.19$ & $3,797.91$ & $3,626.75$ & 171.16 \\
\hline MV-3 PZ & $5,261.17$ & 982.77 & $5 / 22 / 2007$ & $4,278.40$ & $4,120.75$ & $4,060.72$ & 60.03 \\
\hline $\mathrm{HC}-1$ & $5,309.21$ & $1,068.05$ & $5 / 21 / 2007$ & $4,262.04$ & $4,236.01$ & $3,997.12$ & 238.89 \\
\hline $\mathrm{HC}-2$ & $5,347.12$ & $1,089.85$ & $5 / 21 / 2007$ & $4,257.27$ & $4,392.12$ & $4,124.12$ & 268.00 \\
\hline $\mathrm{HC}-3$ & $5,081.52$ & $1,180.15$ & $5 / 22 / 2007$ & $3,901.37$ & $3,918.52$ & $3,898.02$ & 20.50 \\
\hline $\mathrm{HC}-4^{\mathrm{C}}$ & $5,260.90$ & $1,021.76$ & $5 / 21 / 2007$ & $4,239.14$ & $4,247.90$ & $3,957.90$ & 281.00 \\
\hline $\mathrm{HC}-5$ & $5,247.37$ & $1,367.54$ & $5 / 21 / 2007$ & $3,879.83$ & $1,862.37$ & $1,716.77$ & 145.60 \\
\hline $\mathrm{HC}-6$ & $5,228.68$ & 975.20 & $5 / 21 / 2007$ & $4,253.48$ & $4,112.70$ & $3,996.38$ & 116.32 \\
\hline $\mathrm{HC}-7$ & $5,229.72$ & 975.65 & $5 / 21 / 2007$ & $4,254.07$ & $4,123.25$ & $4,006.12$ & 117.13 \\
\hline $\mathrm{HC}-8$ & $5,259.91$ & $1,369.42$ & $5 / 21 / 2007$ & $3,890.49$ & $2,965.51$ & $2,848.99$ & 116.52 \\
\hline
\end{tabular}

TOC = Top of casing (well/piezometer)

TSZ, BSZ (top and bottom of open interval; screened, perforated, or open hole)

${ }^{a}$ Depth-to-water measurements not corrected for borehole deviation

${ }^{\mathrm{b}}$ Corrected for borehole deviation

${ }^{\mathrm{c}}$ Indicates that a transducer was not installed in the well/piezometer. 


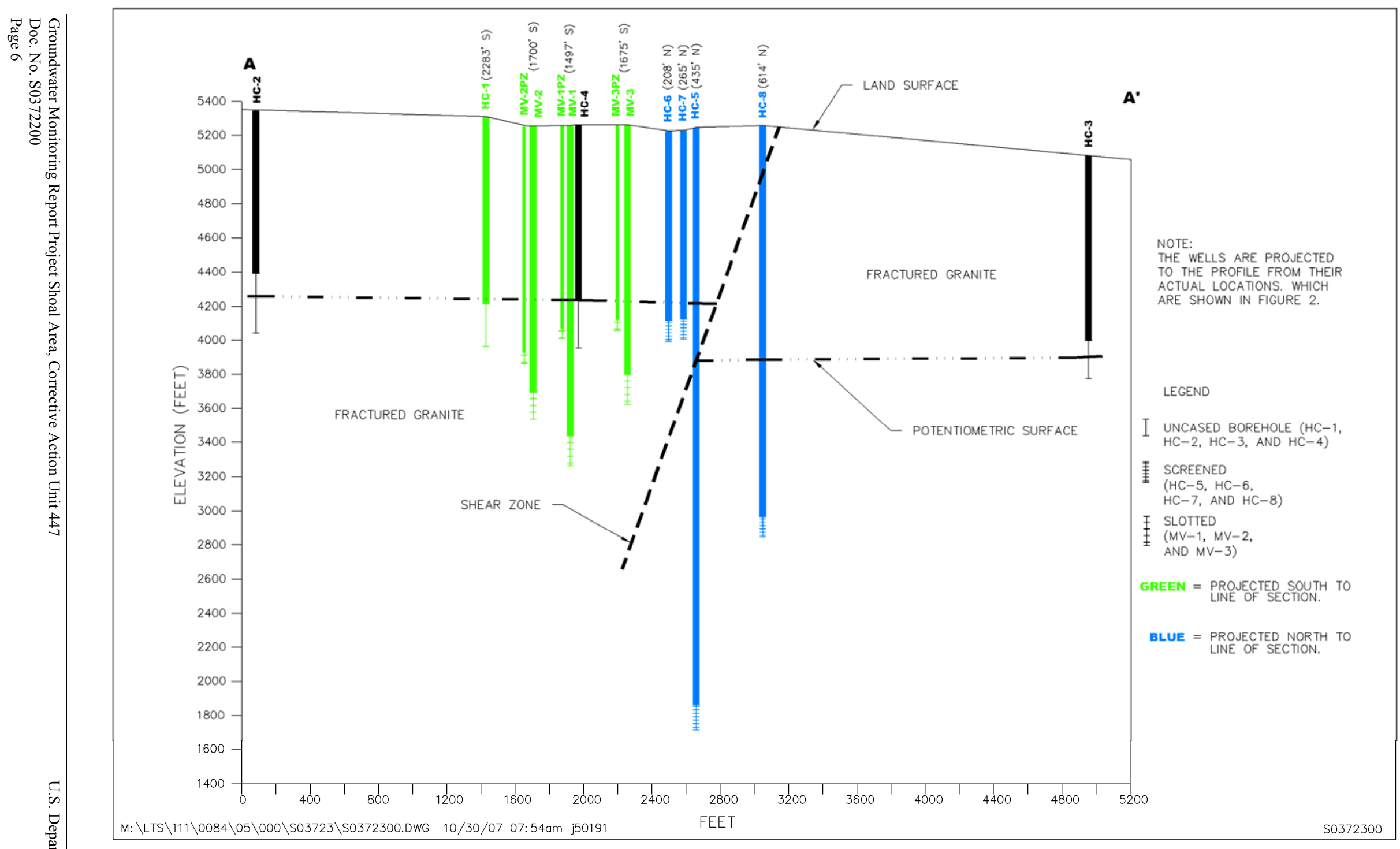

Figure 3. Approximate Location of the Shear Zone 


\subsection{Detection Monitoring}

Detection monitoring at the site is performed by collecting groundwater samples for radioisotopic analyses from the newly installed MV wells and existing site wells $\mathrm{HC}-1$ and HC-4. Samples were collected from the designated wells on March 21, 2007. The DOE-LM Sampling and Analysis Plan (DOE-LM 2006) was used to ensure quality assurance/quality control of the monitoring program at the PSA. Monitoring wells MV-1, MV-2, MV-3, and HC-4 were purged prior to sampling using dedicated submersible pumps. At least one full well volume was removed and field parameters were stabilized before samples were collected from these wells. Samples were collected from well HC-1 by the U.S. Environmental Protection Agency using a depth-specific bailer. The final set of field parameters and well purge volumes is presented in Appendix A.

Groundwater samples were analyzed for tritium, carbon-14 (C-14), iodine-129 (I-129), uranium isotope and gross alpha activities, and mass concentrations of uranium as specified in the $\mathrm{CADD} / \mathrm{CAP}$. Tritium is the analyte selected as an indicator of contaminant migration from the cavity due to its mobility and abundance in the first 100 years of the post-shot monitoring period. However, because of tritium's short half-life, monitoring of C-14 and I-129 will also be conducted in support of long-term post-closure monitoring; data collected in the near term will provide a background/baseline for post-closure monitoring. Elevated gross alpha has been detected in many of the Shoal HC wells. The gross alpha MCL of 15 picocuries per liter $(\mathrm{pCi} / \mathrm{L})$ is exclusive of uranium and radon. Therefore gross alpha and uranium were also selected for analysis; radon volatilizes during sample collection and is an insignificant contributor to gross alpha.

The CADD/CAP (DOE/NNSA 2006) established regulatory levels for site groundwater of $20,000 \mathrm{pCi} / \mathrm{L}$ tritium, 2,000 $\mathrm{pCi} / \mathrm{L} \mathrm{C}-14$, and $1 \mathrm{pCi} / \mathrm{L} \mathrm{I}-129$. These levels are not to be exceeded outside the compliance boundary, which is based on the modeled contaminant boundary (Figure 2). Modeling results indicate that outside the contaminant boundary there is a 95 percent certainty that groundwater will not pose a human health risk (Pohl and Pohlmann 2004). The compliance boundary is contained entirely within the land withdrawn by DOE. The MCLs for adjusted gross alpha and uranium are $15 \mathrm{pCi} / \mathrm{L}$ and 30 micrograms per liter $(\mu \mathrm{g} / \mathrm{L})$, respectively. These constituents are believed to be naturally elevated in groundwater in the region (see further discussion in Section 5.1).

\subsection{System Monitoring}

Monitoring of the groundwater flow system is performed by measuring hydraulic heads in the newly installed MV wells/piezometers and existing wells HC-1 and HC-4. During 2007, hydraulic head data were also collected from the wells HC-2, HC-3, HC-5, HC-6, HC-7, and HC-8 (Figure 2). Head measurements were made at the on-site wells on March 20, 2007, prior to sample collection. A head measurement could not be collected from the MV-2 piezometer because remnant drilling fluid materials in the piezometer tubing prevented the water level tape from reaching the required depth. A head measurement was also not collected from well HC-4 because the well/pump configuration in this well does not provide access for a water level tape.

Transducers were installed in the accessible wells in May 2007 to increase the collection frequency of head data at the site. Prior to the installation of transducers, head measurements were collected from all wells and piezometers except HC-4 using a water level tape or wire line; 
at well HC-4, head is estimated by measuring bubbling pressure on an access tube adjacent to the pump column. Transducers could not be installed in the MV-2 piezometer and well HC-4 due to the same issues that prevented head measurements in March 2007. Head monitoring will be conducted for the 5-year proof-of-concept period. Table 1 lists the wells and piezometers in which transducers were installed.

\subsection{Monitoring Results}

As described in the CADD/CAP, the 2007 monitoring program required the measurement of seven parameters - activities of tritium, C-14, I-129, uranium isotopes, and gross alpha; mass concentrations of uranium, and hydraulic head. Head measurements were made at all wells at the site and are presented in Section 5.2. Radioisotopic and concentration data are presented in Section 5.1.

\subsection{Detection Monitoring Results}

Analytical results from the 2007 monitoring event indicate that tritium concentrations are below the detection limits at all wells. In the past, elevated levels of tritium were detected in well HC-4, providing an indication of a nuclear-test-related signature. This is supported by the elevated level of C-14 in well HC-4 compared to the other monitoring wells. However, all constituents in all wells are below established regulatory levels. A time-concentration plot for well HC-4 (Figure 4) shows that tritium concentrations have been declining over recent years. Estimated activities of C-14 and I-129 are comparable to previous sampling results and continue to provide a baseline for long-term monitoring. Once sufficient data for C-14 and I-129 have been compiled to serve as a representative baseline foundation, sampling frequency for those constituents may be reduced. Data used to calculate radioisotope activities for C-14 are provided in Appendix A.

Table 2 presents a summary of analytical results for C-14, I-129, tritium, uranium, and gross alpha from sampling in March 2007. Uranium (U) mass concentrations detected in samples collected from wells MV-1 and MV-2 exceeded the MCL of $30 \mu \mathrm{g} / \mathrm{L}$. If gross alpha activities shown in Table 2 are adjusted by subtracting activities of ${ }^{234} U$ and ${ }^{238} U$ shown in Table 3, values are below the MCL of $15 \mathrm{pCi} / \mathrm{L}$. The elevated concentrations of uranium are believed to be naturally occurring. It has been demonstrated that ambient groundwater in the region surrounding the site is elevated in concentrations of gross alpha and uranium, among others (Bevans et al. 1998). Elevated uranium concentrations are attributed to leaching from granitic bedrock and associated sediments.

Isotopic ratios of uranium further support a natural source of uranium in groundwater as opposed to a nuclear test-related source. Natural uranium-bearing systems typically have ${ }^{234} \mathrm{U} /{ }^{238} \mathrm{U}$ ratios with a value near 1 (Cowart and Osmond 1977), which is indicative of secular equilibrium between the two isotopes. Table 3 indicates that ratios observed in the PSA samples range from 0.92 to 1.22 - consistent with a natural uranium source. In contrast, average estimates of radionuclides resulting from nuclear tests at the Nevada Test Site suggest a residual source term with a ${ }^{234} \mathrm{U} /{ }^{238} \mathrm{U}$ ratio of approximately 56.25 (Smith 2001). Assuming the residual contamination associated with the PSA is similar to that estimated by Smith (2001), the ${ }^{234} \mathrm{U} /{ }^{238} \mathrm{U}$ ratio would be expected to be much higher than those observed if the uranium was derived from leaching of the test cavity. 
Table 2. Radioisotopic and Chemical Sampling Results

\begin{tabular}{|c|c|c|c|c|c|c|}
\hline $\begin{array}{l}\text { Monitoring } \\
\text { Location }\end{array}$ & Date & $\begin{array}{l}\text { Carbon-14 } \\
\text { (pCi/L) }\end{array}$ & $\begin{array}{l}\text { lodine-129 } \\
\text { (pCi/L) }\end{array}$ & $\begin{array}{l}\text { Tritium } \\
\text { (pCi/L) }\end{array}$ & $\begin{array}{c}\text { Uranium } \\
(\mu \mathrm{g} / \mathrm{L})\end{array}$ & $\begin{array}{l}\text { Gross alpha } \\
\text { (pCi/L, total } \\
\text { unadjusted) }\end{array}$ \\
\hline $\begin{array}{l}\text { MV-1 } \\
\text { (unfiltered) }\end{array}$ & $3 / 21 / 2007$ & $<\mathrm{RDL}(5.83 \mathrm{E}-3)$ & $<\mathrm{RDL}(7.3 \mathrm{E}-11)$ & $<359$ & 42 & 25.6 \\
\hline $\mathrm{MV}-1$ & $3 / 21 / 2007$ & NS & NS & NS & 41 & 21.5 \\
\hline $\begin{array}{l}\text { MV-2 } \\
\text { (unfiltered) }\end{array}$ & $3 / 21 / 2007$ & $<\operatorname{RDL}(.0177)$ & $<\mathrm{RDL}(8.3 \mathrm{E}-11)$ & $<351$ & 34 & 16.3 \\
\hline MV-2 & $3 / 21 / 2007$ & NS & NS & NS & 34 & 17.3 \\
\hline $\begin{array}{l}\text { MV-3 } \\
\text { (unfiltered) }\end{array}$ & $3 / 21 / 2007$ & $<\mathrm{RDL}(5.90 \mathrm{E}-3)$ & $<\operatorname{RDL}(13.5 \mathrm{E}-11)$ & $<357$ & 14 & 10.2 \\
\hline MV-3 & $3 / 21 / 2007$ & NS & NS & NS & 14 & 9.57 \\
\hline $\begin{array}{l}\mathrm{HC}-1 \\
\text { (unfiltered) }\end{array}$ & $3 / 21 / 2007$ & $<\operatorname{RDL}(.0152)$ & $<\mathrm{RDL}(9.6 \mathrm{E}-11)$ & $<355$ & 3.3 & 3.9 \\
\hline $\mathrm{HC}-1$ & $3 / 21 / 2007$ & NS & NS & NS & 3.4 & 4.46 \\
\hline $\begin{array}{l}\mathrm{HC}-4 \\
\text { (unfiltered) }\end{array}$ & $3 / 21 / 2007$ & <RDL (.565) & $<\mathrm{RDL}(32.4 \mathrm{E}-11)$ & $<359$ & 0.75 & 1.41 \\
\hline $\mathrm{HC}-4$ & $3 / 21 / 2007$ & NS & NS & NS & 0.85 & 1.93 \\
\hline $\begin{array}{l}\mathrm{HC}-4 \\
\text { (unfiltered) }\end{array}$ & $3 / 21 / 2007$ & $<\operatorname{RDL}(.436)$ & $<\mathrm{RDL}(34.2 \mathrm{E}-11)$ & $<359$ & 0.69 & 1.75 \\
\hline $\mathrm{HC}-4$ & $3 / 21 / 2007$ & NS & NS & NS & 0.81 & $<0.876$ \\
\hline
\end{tabular}

aestimated based on sample volume of $200 \mathrm{~mL}$

$\angle \mathrm{RDL}=$ below required detection limit with laboratory result in parentheses

NS =not sampled

Table 3. Uranium Isotopic Sampling Results

\begin{tabular}{||c|c|c|c|c||}
\hline \multicolumn{1}{|c|}{$\begin{array}{c}\text { Monitoring } \\
\text { Location }\end{array}$} & Date & $\begin{array}{c}\text { Uranium-234 } \\
(\mathbf{p C i} / \mathbf{L})\end{array}$ & $\begin{array}{c}\text { Uranium-238 } \\
(\mathbf{p C i} / \mathbf{L})\end{array}$ & $\mathbf{U}^{\mathbf{2 3 4} / \mathbf{U}^{\mathbf{2 3 8}}}$ \\
\hline $\mathrm{MV}-1$ & $3 / 21 / 2007$ & 16.8 & 14.2 & 1.18 \\
\hline $\mathrm{MV}-1$ (unfiltered) & $3 / 21 / 2007$ & 15.4 & 12.6 & 1.22 \\
\hline MV-2 & $3 / 21 / 2007$ & 13.6 & 11.4 & 1.19 \\
\hline MV-2 (unfiltered) & $3 / 21 / 2007$ & 13.2 & 11.7 & 1.13 \\
\hline MV-3 & $3 / 21 / 2007$ & 4.64 & 4.37 & 1.06 \\
\hline MV-3 (unfiltered) & $3 / 21 / 2007$ & 5.47 & 4.68 & 1.17 \\
\hline HC-1 & $3 / 21 / 2007$ & 1.28 & 1.19 & 1.08 \\
\hline HC-1 (unfiltered) & $3 / 21 / 2007$ & 1.4 & 1.19 & 1.18 \\
\hline HC-4 & $3 / 21 / 2007$ & 0.349 & 0.308 & 1.12 \\
\hline HC-4 & $3 / 21 / 2007$ & 0.313 & 0.33 & 0.95 \\
\hline HC-4 (unfiltered) & $3 / 21 / 2007$ & 0.293 & 0.305 & 0.96 \\
\hline HC-4 (unfiltered) & $3 / 21 / 2007$ & 0.31 & 0.336 & 0.92 \\
\hline
\end{tabular}




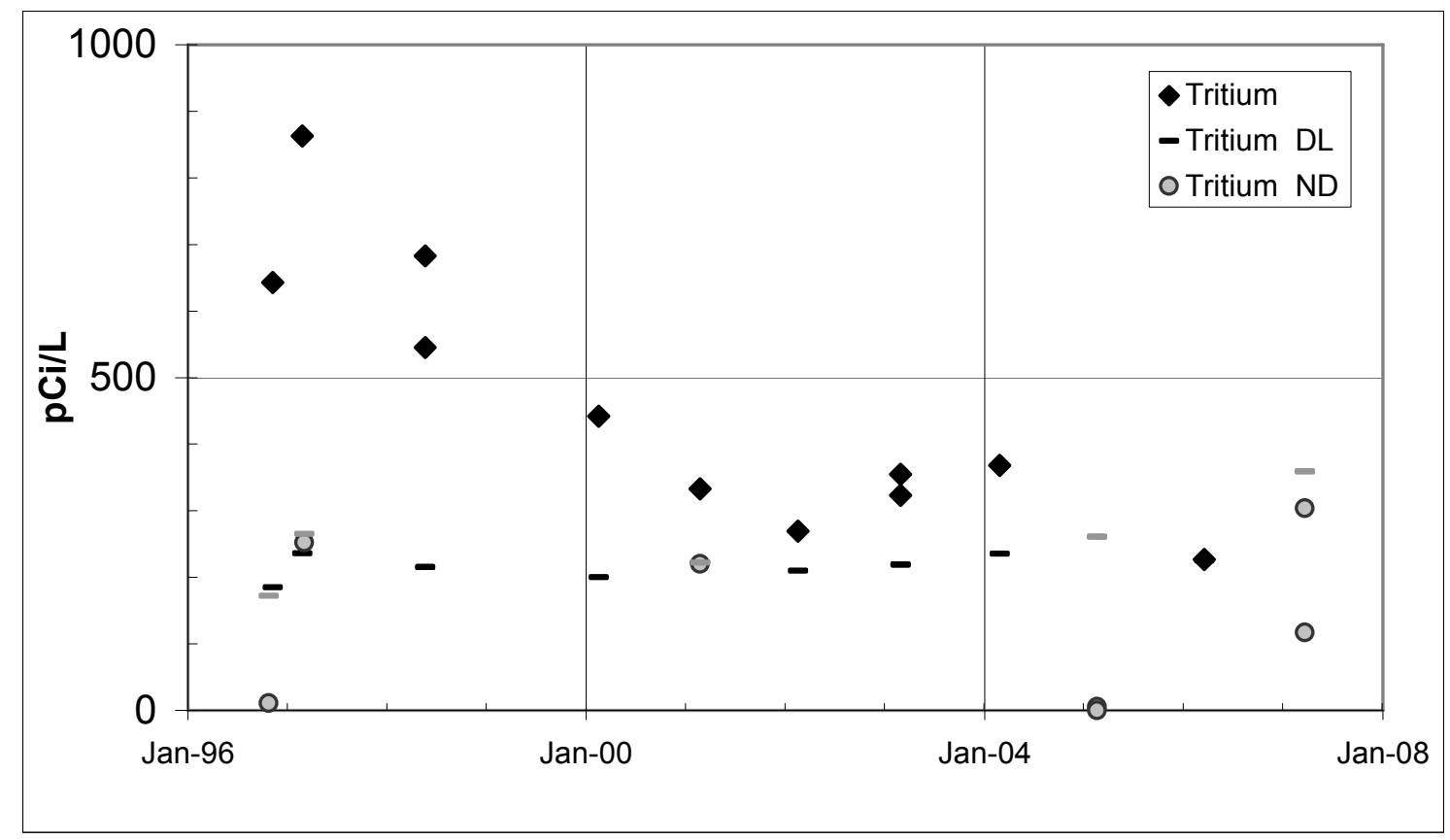

$\mathrm{DL}=$ detection limit

ND = below detection limit

Figure 4. Time-Concentration Plot of Tritium at Well HC-4

\subsection{System Monitoring Results}

Hydrographs of hydraulic head data from site monitoring events during 2006 and 2007 are shown in Figure 5 and Figure 6. The head data for 2006 are from a groundwater monitoring event conducted by DRI on March 30 of that year prior to drilling the MV wells. The 2007 head data were obtained during the March 2007 sampling event and by transducer data recorded from May through July 2007. The transducers provide a continuous record (every hour or few hours) of water levels in wells and piezometers at the site. This allows seasonal variability and other effects, such as the recovery of water levels from yearly sampling events, to be identified and considered when calculating and interpreting hydraulic gradients at the site.

Hydrographs are grouped according to the location of each well's open interval relative to the north-northeast trending shear zone that transects the site. Monitoring points west of the shear zone include the MV-1, MV-2, and MV-3 wells and piezometers, and wells HC-1, HC-2, HC-4, HC-6, and HC-7 (Figure 5). Head levels east of the shear zone are monitored by wells HC-3, HC-5, and HC-8 (Figure 6). Head levels in wells west of the shear zone (detonation side) are generally 250 to $300 \mathrm{ft}$ higher than those in wells east of the shear zone. 


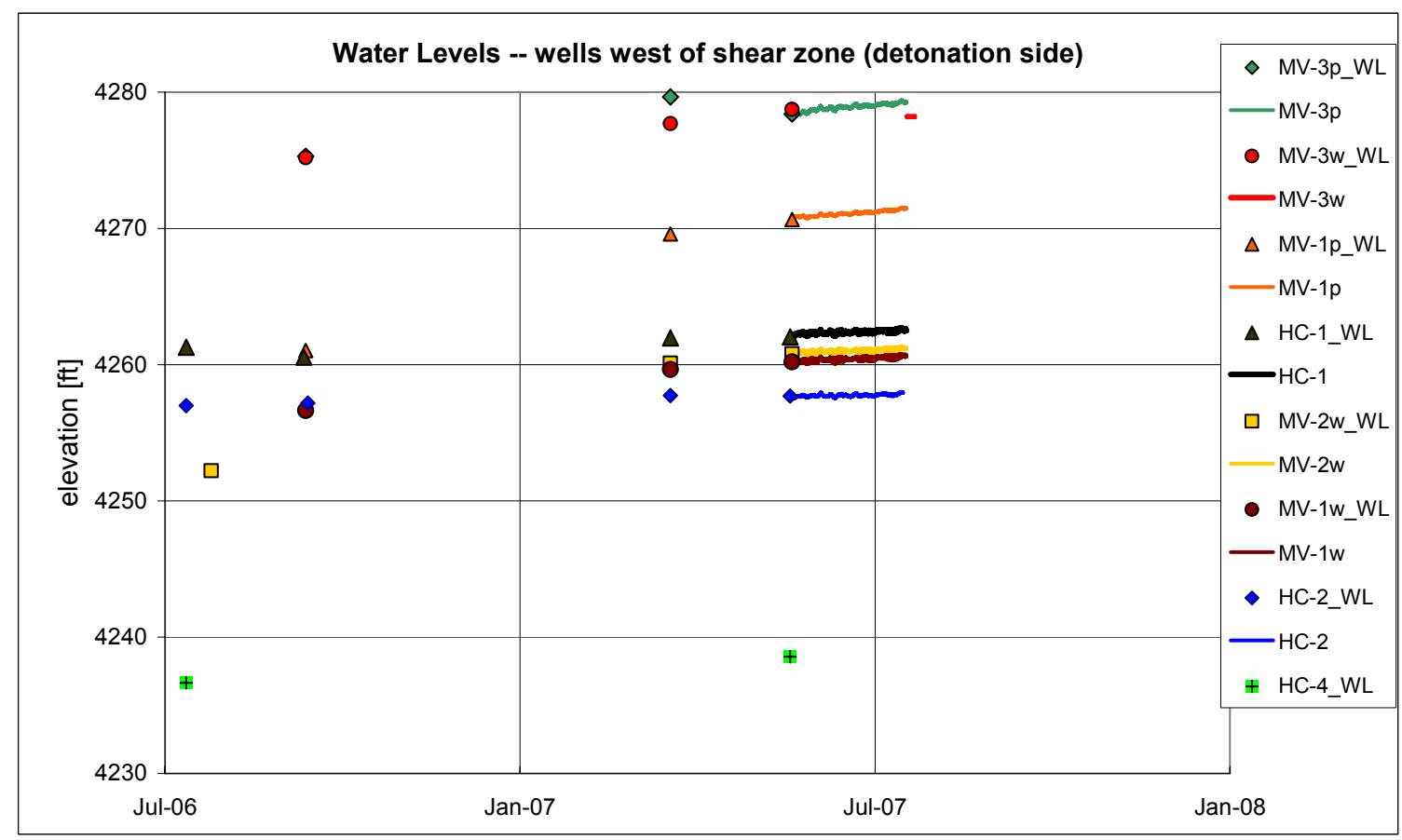

Figure 5. Hydrographs for Wells West of the Shear Zone

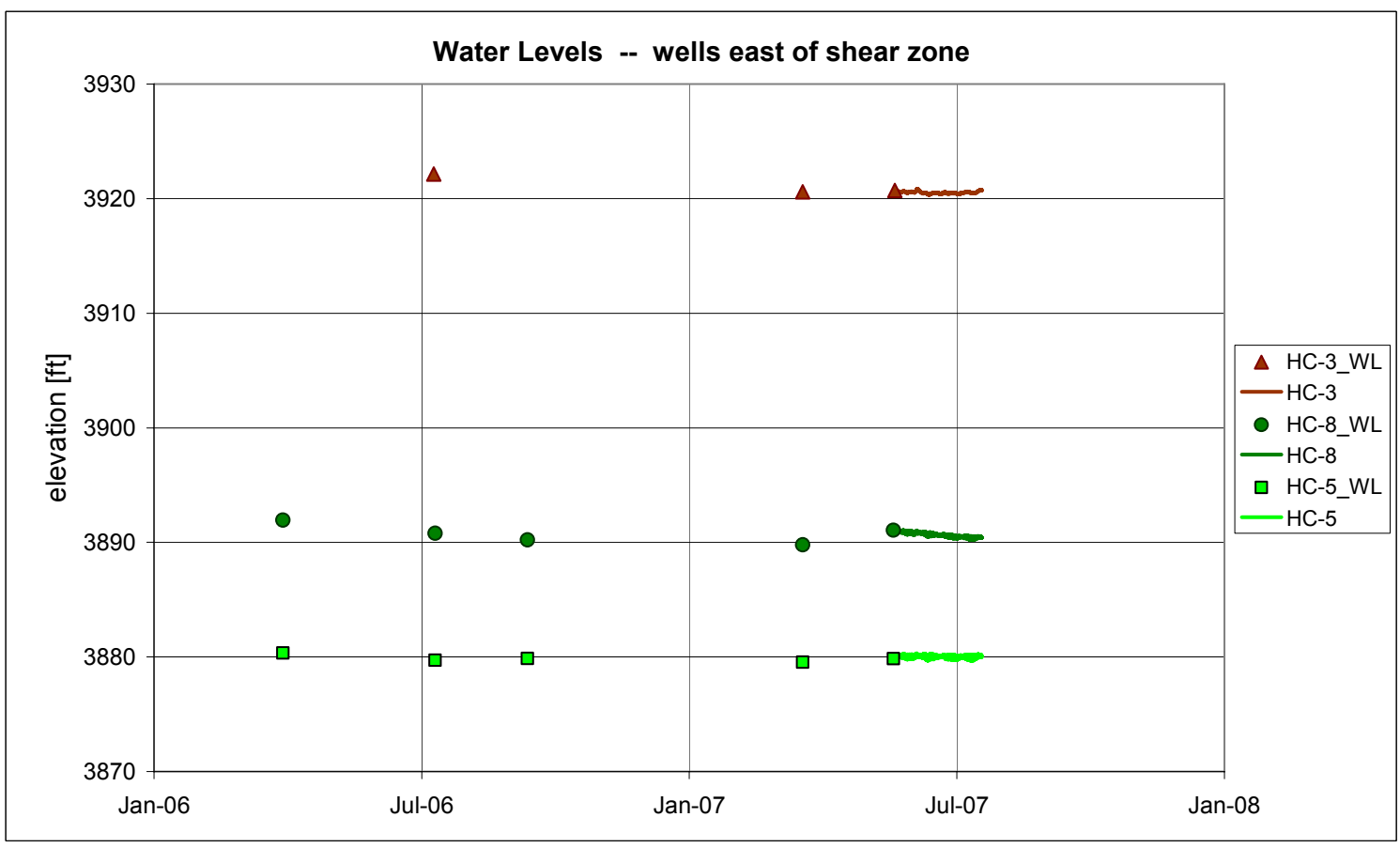

Figure 6. Hydrographs for Wells East of the Shear Zone 


\subsection{Summary}

The data collected in 2007 provide a baseline for proof-of-concept monitoring. Current concentrations of tritium, C-14, and I-129 are below established regulatory levels. Analytical results from well $\mathrm{HC}-4$ have a nuclear-test-related signature for $\mathrm{C}-14$, however, concentrations are below the established regulatory level of $2,000 \mathrm{pCi} / \mathrm{L}$. Tritium concentrations in this well have decreased significantly since a high of $1,130 \mathrm{pCi} / \mathrm{L}$ was reported in 1998 (Pohll et al. 1998) and remain well below the tritium MCL of 20,000 pCi/L. Elevated concentrations of uranium, which exceed the MCL, are attributed to natural sources. An evaluation of the stability of the hydrologic system will be made after data have been collected over a longer period of time.

\subsection{References}

AEC (U.S. Atomic Energy Commission/Nevada Operations Office), 1964. Project Manager's Report, Project Shoal, NVO-11, Las Vegas, Nevada, May.

AEC (U.S. Atomic Energy Commission/Nevada Operations Office), 1970. Site Disposal Report Fallon Nuclear Test Site (Shoal) Churchill County, Nevada, NVO-73, Las Vegas, Nevada.

Beal, L.H., S.E. Jerome, I. Lutsey, R.H. Olson, and J.H Schilling, 1964. "Geology of the Sand Springs Range," Nevada Bureau of Mines and Geology, Final Report, Geological, Geophysical, Chemical and Hydrological Investigations of the Sand Springs Range, Fairview Valley, and Fourmile Flat, Churchill County, Nevada, for Shoal Event, Project Shade, Vela Uniform Program, United States Atomic Energy Commission.

Bevans, H.E., M.S. Lico, and S.J. Lawrence, 1998. Water quality in the Las Vegas Valley Area and the Carson and Truckee River Basins, Nevada and California, 1992-96, Circular 1170, U.S. Geological Survey, U.S. Department of the Interior, Carson City, Nevada.

Cowart, J.B., and J.K. Osmond, 1977. "Uranium Isotopes in Groundwater: Their Use in Prospecting for Sandstone-type Uranium Deposits," Journal of Geochemical Exploration, 8: 365-379.

DOE-LM (U.S. Department of Energy, Office of Legacy Management), 2006. Sampling and Analysis Plan for U.S. Department of Energy Office of Legacy Management Sites, DOE-LM/GJ1197-2006.

DOE/NNSA (U.S. Department of Energy, National Nuclear Security Administration), 2006. Corrective Action Decision Document/Corrective Action Plan for Corrective Action Unit 447: Project Shoal Area, Subsurface, Nevada, DOE/NV-1025, Rev. 3, Las Vegas, Nevada.

DOE/NV (U.S. Department of Energy/Nevada Operations Office), 1998. Closure Report for Corrective Action Unit 416: Project Shoal Area, DOE/NV--11718-179-Rev. 0, Las Vegas, Nevada, January. 
FFACO, 2005. Federal Facility Agreement and Consent Order (FFACO), January.

Hassan, A., 2004. Validation, Proof-of-Concept, and Postaudit of the Groundwater Flow and Transport Model of the Project Shoal Area, Publication No. 45206, DOE/NV/13609-35, September.

Hazleton-Nuclear Science Corporation, 1965. Vela Uniform Project Shoal Fallon, Nevada, VUF-1014, Post-Shot Hydrologic Safety, October 30, 1965.

NDEP (Nevada Division of Environmental Protection), 1998. Letter of Acceptance of Closure Report for CAU 416, Project Shoal Area Surface, Nevada Division of Environmental Protection, Las Vegas, Nevada, February 13, 1998.

Pohll, G, J. Chapman, A. Hassan, C. Papelis, R. Andricevic, and C. Shirley, 1998. Evaluation of Groundwater Flow and Transport at the Shoal Underground Nuclear Test: An Interim Report, Publication No. 45162, DOE/NV/11508-35, UC-703, July.

Pohll, G., and K. Pohlmann, 2004. Contaminant Boundary at the Shoal Underground Nuclear Test, Letter Report, DOE/NV--993, August 6.

Smith, D.K., 2001. Unclassified Radiological Source Term for the Nevada Test Site Areas 19 and 20, URCL-ID-141706. Lawrence Livermore National Laboratory, Livermore, California. 


\section{End of current text}

Page 14 


\section{Appendix A}

Carbon-14 Calculation Data and Well Purge Data 
This page intentionally left blank 
Table A-1. Monitor Well Purge Data

\begin{tabular}{|c|c|c|c|c|c|}
\hline Well & $\begin{array}{c}\text { Date } \\
\text { Sampled }\end{array}$ & $\begin{array}{l}\text { Purged Volume } \\
\text { (gallons) }\end{array}$ & $\begin{array}{c}\text { Temperature } \\
\left({ }^{\circ} \mathrm{C}\right)\end{array}$ & $\begin{array}{c}\text { pH } \\
\text { (s.u.) }\end{array}$ & $\begin{array}{c}\text { Specific } \\
\text { Conductance } \\
(\mu \mathrm{mhos} / \mathrm{cm})\end{array}$ \\
\hline \multirow{3}{*}{$M V-1$} & \multirow{3}{*}{$3 / 21 / 2007$} & \multirow{3}{*}{2,800} & 21.7 & 7.68 & 756 \\
\hline & & & 21.6 & 7.68 & 754 \\
\hline & & & 21.5 & 7.69 & 754 \\
\hline \multirow{3}{*}{ MV-2 } & \multirow{3}{*}{$3 / 21 / 2007$} & \multirow{3}{*}{1,720} & 21.5 & 7.64 & 556 \\
\hline & & & 22.2 & 7.68 & 553 \\
\hline & & & 22.2 & 7.68 & 552 \\
\hline \multirow{3}{*}{ MV-3 } & \multirow{3}{*}{$3 / 21 / 2007$} & \multirow{3}{*}{2,530} & 20.9 & 7.58 & 853 \\
\hline & & & 20.7 & 7.59 & 851 \\
\hline & & & 20.8 & 7.63 & 850 \\
\hline $\mathrm{HC}-1$ & $3 / 21 / 2007$ & $\mathrm{~N} / \mathrm{A}$ & 16.1 & 7.60 & 415 \\
\hline \multirow{2}{*}{$\mathrm{HC}-4$} & \multirow{2}{*}{$3 / 21 / 2007$} & \multirow{2}{*}{268} & 19.1 & 7.80 & 758 \\
\hline & & & 20.7 & 7.60 & 783 \\
\hline
\end{tabular}

s.u. = Standard Unit

$\mu \mathrm{mhos} / \mathrm{cm}=$ micromhos per centimeter

Table A-2. Carbon-14 Radioisotope Calculation Data

\begin{tabular}{|c|c|c|c|c|c|c|c|c|}
\hline Well ID & $\begin{array}{l}\text { Sample } \\
\text { Date }\end{array}$ & $\begin{array}{c}\text { Mass } \\
\text { C } \\
(\mathrm{mg})\end{array}$ & $\delta^{13} \mathrm{C}(\%)$ & $\begin{array}{c}\mathrm{C}-14 \\
(\mathrm{pmc})\end{array}$ & $\begin{array}{l}\text { Fraction } \\
\text { mc }\end{array}$ & $\pm 1 \mathrm{~s}$ & $\mu \mathrm{Ci} / \mathrm{mg} \mathrm{C}^{\mathrm{a}}$ & $\mathrm{pCi} / \mathrm{L}^{\mathrm{b}}$ \\
\hline MV-1 & $3 / 21 / 07$ & 0.80 & -11.2 & 23.75 & 0.2375 & 0.0019 & 1.46E-09 & $5.83 E-03$ \\
\hline MV-2 & $3 / 21 / 07$ & 1.59 & -10.9 & 36.21 & 0.3621 & 0.002 & $2.22 \mathrm{E}-09$ & 1.77E-02 \\
\hline MV-3 & $3 / 21 / 07$ & 0.86 & -11.9 & 22.36 & 0.2236 & 0.0016 & 1.37E-09 & $5.90 \mathrm{E}-03$ \\
\hline $\mathrm{HC}-1$ & $3 / 21 / 07$ & 1.12 & -9.5 & 44.37 & 0.4437 & 0.0022 & $2.72 \mathrm{E}-09$ & $1.52 \mathrm{E}-02$ \\
\hline $\mathrm{HC}-4$ & $3 / 21 / 07$ & 2.33 & -2.9 & 790.1 & 7.901 & 0.025 & 4.85E-08 & $5.65 \mathrm{E}-01$ \\
\hline $\begin{array}{l}\mathrm{HC}-4 \\
\text { (unfiltered) }\end{array}$ & $3 / 21 / 07$ & 1.8 & -2.6 & 790.3 & 7.903 & 0.025 & 4.85E-08 & 4.36E-01 \\
\hline
\end{tabular}

${ }^{a}$ Modern C-14 standard at 1950 AD has activity of $13.6 \mathrm{dpm} / \mathrm{gram} \mathrm{C}=0.000227 \mathrm{dps} / \mathrm{mg} \mathrm{C}$.

$1 \mu \mathrm{Ci}=3.7 \times 10^{4} \mathrm{dps}$; therefore, modern $\mathrm{C}-14$ standard at $1950 \mathrm{AD}$ has activity of $6.135 \times 10^{-9} \mu \mathrm{Ci} / \mathrm{mg}$.

${ }^{b}$ Assumes $200 \mathrm{~mL}$ sample used to obtain mass of carbon.

$\mathrm{pmc}=$ percent modern carbon; $\mathrm{mc}=$ modern carbon; $\mathrm{s}=$ standard deviation 


\section{End of current text}

